1. Werner C W, Seymour R A. Are alcohol containing mouthwashes safe? Br Dent J 2009; 207: E19.

2. Speight P. Summary of: Are alcohol containing mouthwashes safe? Br Dent J 2009; 207: 488-489.

3. Warnakulasuriya S. Causes of oral cancer - an appraisal of controversies. Br Dent J 2009. 207: 471-475.

4. Hyatt A T. Diminished, sidelined. Br Dent J 2009 207: 463.

5. McCullough M J, Farah C S. The role of alcohol in oral carcinogenesis with particular reference to alcohol-containing mouthwashes. Aust Dent J 2008; 53: 302-305.

6. La Vecchia C. Mouthwash and oral cancer risk: an update. Oral Oncol 2009; 45: 198-200.

7. Cole P, Rodu B, Mathisen A. Alcohol-containing mouthwash and oropharyngeal cancer: a review of the epidemiology. J Am Dent Assoc 2003; 134: 1079-1087.

8. Winn D M, Blot W J, McLaughlin J K et al. Mouthwash use and oral conditions in the risk of oral and pharyngeal cancer. Cancer Res 1991; 51: 3044-3047.

9. Lachenmeier D W. Safety evaluation of topical applications of ethanol on the skin and inside the oral cavity. J Occup Med Toxicol 2008; 3: 26.

10. Lachenmeier D W, Gumbel-Mako S, Sohnius E M, Keck-Wilhelm A et al. Salivary acetaldehyde increase due to alcohol-containing mouthwash use: a risk factor for oral cancer. Int J Cancer 2009; 125: 730-735.

11. Secretan B, Straif $K$, Baan $R$ et al. A review of human carcinogens - Part E: tobacco, areca nut, alcohol, coal smoke, and salted fish. Lancet Oncol 2009; 10: 1033-1034.

DOI: 10.1038/sj.bdj.2010.110

\section{AN UNVIABLE APPROACH}

Sir, I have followed the recent series of papers on the role of the dental therapist with interest. They describe attempts to follow a path trodden by the hygienists some years ago, when it was proposed to allow hygienists to set up independent practices. The laws allowing them to work without dentist supervision and more importantly handle payments directly - were never passed. I do not remember any public debate as to why this never happened, but I suspect that when it was discovered that independent hygienists would charge the same to the patients as those working within a dental practice there was little incentive to allow full independence. The discussion of cost-effectiveness of therapists by the authors ${ }^{1}$ goes over much the same ground. When the costs of the legally required nurse/chaperone are added to the low earning potential of a therapist working under NHS contract the whole concept of independent therapists becomes uneconomic. There is no way in which dentistry can be provided on the cheap in the UK by the equivalent of a third world 'barefoot doctor'; the regulations over how we deliver dentistry make this approach unviable. If cost control to government and patient is a priority why not ask the profession how it can be done? I am sure that many dentists would welcome a full and frank discussion and help to create a system of dental care appropriate to current conditions.

\section{S. W. White \\ Shanklin}

1. Williams S A, Bradley S, Godson J H, Csikar J I, Rowbotham J S. Dental therapy in the United Kingdom: part 3. Financial aspects of current working practices. Br Dent J 2009; 207: 477-483.

DOI: 10.1038/sj.bdj.2010.111

\section{FAMILIAR FORCEPS}

Sir, I have been interested in the advert you published recently regarding a new line of dental forceps - 'Physics Forceps from General Medical'. What fascinated me the most was the claim that these forceps were a revolutionary design using a beak and buffer principle. But are they?

Now it is a fact that I have been involved with the dental world for several decades, and casting my mind back I cannot help but notice the similarity of this revolutionary design to the robust and reliable pelican noted for its use in Cromwell's day, and also in Hampton Court some years before that to deprive Good Queen Bess of yet another troublesome tooth. All more than 400 years ago.

The Physics Forceps also bear a very close resemblance to the well known and equally robust dental extractor the 'Tooth Key' both of which instruments also use the by now familiar beak and bumper design. If you ask the curator of the BDA Museum nicely she will no doubt show you examples of both types.

Perhaps it is well that copyright only extends for 50 years after the designer's death. Or is it possible that somewhere in an English field there lays the body of a well known tooth-puller to Lord Protector Cromwell? Maybe the marketplace tooth-puller feeling spiteful at being deprived of his 5\% for the last four centuries, will arise from his grave at midnight, vampire-like, and pursue all those colleagues of mine who forgot to pay the $5 \%$ to original designer of these useful but rather outdated dental tools.
But, to those of my colleagues who have purchased these interesting Physics Forceps, and have been foolish enough not to pay the dental phantom, be warned, do not whistle at midnight under a full moon, or even cross the Grimpen Mire at night.

P. Jeavons

Sheffield

DOI: 10.1038/sj.bdj.2010.112

\section{SPIRALLING COSTS}

Sir, we know that payment of a retention fee to the General Dental Council is mandatory. I did, however, enclose with it a note asking where the money was being used.

They have at least responded with a letter from a 'Process improvement Coordinator'. Thirty-eight percent of their 2008 expenditure was utilised on fitness to practise activity. I do therefore wonder whether the other $62 \%$ was merely used to maintain an expensive office!

To make matters worse, I now have an annual retention fee notice from the General Medical Council for $£ 410.00$. When first registering with the GMC, this was agreed to be a 'one-off payment'.

I do wonder where this is all spiralling. Perhaps you will publish my concerns, in order that colleagues may have the opportunity of joining with me in a response to these now non-professional bureaucracies.

$$
\begin{array}{r}
\text { B. Littler } \\
\text { Chelmsford }
\end{array}
$$

\section{CAVALIER ATTITUDE}

Sir, over the years I have prescribed Adcortyl in Orabase (triamcinolone acetonide $0.1 \%$ ) for patients with recurrent oral ulceration. More recently it has been available as an over the counter' medicine.

I have been told by a number of patients that it is no longer available as it has been withdrawn. They could obtain no further information.

This prompted me to make enquiries on their behalf. I visited the DPF website where Adcortyl in Orabase is still listed.

I then contacted the manufacturers, Squibb Pharmaceuticals, who informed me that it had been withdrawn for "commercial reasons'. When I asked how that 